\title{
Long-term Efficacy of Upstream Therapy With Lipophilic or Hydrophilic Statins on Antiarrhythmic Drugs in Patients With Paroxysmal Atrial Fibrillation
}

\author{
Comparison Between Atorvastatin and Pravastatin
}

\author{
Takashi Komatsu, ${ }^{1}$ MD, Hideaki Tachibana, ${ }^{1}$ MD, Yoshihiro Sato, ${ }^{1}$ MD, Mahito Ozawa,,${ }^{1}$ MD, \\ Fusanori Kunugita, ${ }^{1} \mathrm{MD}$, and Motoyuki NaKamura, ${ }^{1} \mathrm{MD}$
}

\begin{abstract}
SUMMARY
There is little information available on the benefits of selection of statins as upstream therapy for the prevention of paroxysmal atrial fibrillation (AF). We compared the efficacy and safety of atorvastatin (A-group, $n=43$ ) and pravastatin (P-group, $n=41$ ) as upstream therapy in patients with paroxysmal $\mathrm{AF}$ and dyslipidemia. A total of 84 patients (45 men, mean age, $66 \pm 9$ years, mean follow-up, $49 \pm 32$ months) were retrospectively assigned to receive atorvastatin $(n=$ $41 ; 10 \mathrm{mg} /$ day) or pravastatin $(n=43 ; 10 \mathrm{mg} /$ day). Survival rates free from AF recurrence at $1,6,12$, and 24 months were $93 \%, 74 \%, 60 \%$, and $53 \%$ in A-group, and 88\%, 49\%, 37\%, and 29\%, respectively, in P-group ( $P=0.029$, Agroup versus P-group). Survival rates free from conversion to permanent AF at 12, 36, 60, and 90 months were $100 \%$, $100 \%, 98 \%$, and $95 \%$ in A-group, and $100 \%, 95 \%, 88 \%$, and $83 \%$, respectively, in P-group $(P=0.063$, A-group versus P-group). Using a logistic regression model, atorvastatin was found to be associated with a significantly reduced risk of $\mathrm{AF}$ recurrence in comparison to pravastatin (unadjusted odds ratio $[\mathrm{OR}]=0.27,95 \%$ confidence interval $0.11-0.68, P=$ $0.005)$. This association remained significant after adjustment for potentially confounding variables $(\mathrm{OR}=0.26,95 \% \mathrm{CI}$ $0.08-0.86, P=0.027)$. Using a logistic regression model, atorvastatin was not associated with a significantly reduced risk of converting to permanent $\mathrm{AF}$ in comparison to pravastatin (unadjusted $\mathrm{OR}=0.29,95 \% \mathrm{CI} 0.05-1.50, P=0.138$ ), but this association did show a significant difference after adjustment for potentially confounding variables in a multivariate model $(\mathrm{OR}=0.08,95 \% \mathrm{CI} 0.06-0.96, P=0.046)$. Adverse effects requiring discontinuation of statins were observed in 1 case $(2 \%$, myalgia) in A-group, and 1 case (2\%, elevation in CPK level $\geq 500 \mathrm{IU} / \mathrm{L})$ in P-group, respectively $(P=\mathrm{NS}$, A-group versus P-group). Atorvastatin, a lipophilic statin, was considered to be more effective in preventing recurrence of paroxysmal AF and conversion to permanent AF than pravastatin, a hydrophilic statin. (Int Heart J 2011; 52: 359$365)$
\end{abstract}

Key words: Atrial fibrillation, Prophylactic efficacy, Upstream therapy, Atorvastatin, Pravastatin

A ccording to a large-scale epidemiological survey performed in Western countries, atrial fibrillation (AF), which is often encountered in daily practice, is an independent risk factor for cardiovascular death, ${ }^{1)}$ and the risk of such death is 2-3 times higher in patients with $\mathrm{AF}$ than in those with sinus rhythm. ${ }^{2)}$

$\mathrm{AF}$ is an arrhythmia that should be actively treated and controlled, because it not only causes cardiovascular complications, including thromboembolism and heart failure, ${ }^{2}$ but also decreases survival in patients with impaired left ventricular function. ${ }^{3)}$

The number of patients with AF in the United States exceeded 5 million in 2000 and is expected to increase two to threefold over the next 50 years. ${ }^{4)}$ In Japan, the population is aging rapidly and the prevalence of AF among elderly persons aged 70 years or older is already around $3 \%$. This is expected to increase to about $4.5 \%$ over the next 20 years. ${ }^{5)} \mathrm{AF}$ is now recognized as a significant medical and social problem.

The Japanese Circulation Society (JCS) guidelines ${ }^{6}$ recommend that antiarrhythmic drug therapy be selected as firstline therapy for preventing recurrence of paroxysmal $\mathrm{AF}$ associated with or without underlying heart disease, whereas antiarrhythmic drug therapy aiming at maintenance of sinus rhythm has prognostic limitations. ${ }^{7}$ Recently, attention has been paid to upstream treatment, in which antiarrhythmic drug therapy is combined with statins ${ }^{8-10)}$ to modify the arrhythmic substrate of the atrial myocardium which is the underlying cause of $\mathrm{AF}$.

In all of these studies, different statins were administered based on the theory that their beneficial or antiarrhythmic efficacies are to some extent similar. On the other hand, there are data that indicate the so-called pleiotropic actions among dif-

From the ${ }^{1}$ Division of Cardiology, Department of Internal Medicine and Memorial Heart Center, Iwate Medical University School of Medicine, Iwate, Japan. Address for correspondence: Takashi Komatsu, MD, Division of Cardiology, Department of Internal Medicine and Memorial Heart Center, Iwate Medical University School of Medicine, 19-1 Uchimaru, Morioka, Iwate 020-8505, Japan.

Received for publication April 28, 2011.

Revised and accepted July 21, 2011 
ferent statins can differ considerably. ${ }^{11-14)}$ We hypothesized that patients with more potent lipophilic statin therapy would be less prone to AF recurrence than those treated with a less potent hydrophilic statin. To the best of our knowledge, no similar clinical studies have yet been reported.

In this study, we retrospectively compared the long-term efficacy and safety of upstream therapy using atorvastatin or pravastatin in combination with antiarrhythmic drugs for the prevention of $\mathrm{AF}$ recurrence in patients with paroxysmal AF.

\section{Methods}

Subjects: Subjects were recruited from a total pool of 505 paroxysmal AF patients who had symptoms such as palpitations and electrocardiographic evidence of AF corresponding to those symptoms. The study sample comprised 84 patients (45 men and 39 women, mean age, $66 \pm 9$ years) with dyslipidemia and/or elevated cardiovascular risk who were receiving statin therapy according to the guidelines. All of these patients visited our facility periodically at intervals of 2-4 weeks and were followed for one year or longer. Subjects were divided into two groups: patients treated with pravastatin (a hydrophilic statin; $10 \mathrm{mg} /$ day, $n=41$ ) and those treated with atorvastatin (a lipophilic statin; $10 \mathrm{mg} / \mathrm{day}, n=43$ ). In 35 patients, statin therapy was started one month before inclusion, whereas in 49 patients statins were administered for a longer period prior to inclusion.

Antiarrhythmic drugs were selected by the attending physician. To confirm the recurrence of AF, symptoms were assessed by interview and standard 12-lead ECG after commencement of antiarrhythmic therapy or at 2-4 weeks after a change in therapy. ECG was performed with a portable monitor at the time of medical examination, and an ambulatory 24hour ECG was repeated every 3 months to detect recurrence of $\mathrm{AF}$, if this was considered necessary by the attending physician.

In addition, at every visit to our outpatient clinic, maintenance or otherwise of sinus rhythm was confirmed with the use of a portable ECG monitor (IEC-1101 "Heart Mate" manufactured by Nihon Kohden Corporation). For measurement of human atrial natriuretic peptide (ANP) during sinus rhythm, venous blood was collected from an upper limb after the patient had rested in the supine position if no palpitations had been noted since the start of drug therapy and sinus rhythm was confirmed on ECG at each hospital visit. Whenever palpitations occurred, ambulatory 24-hour monitoring was conducted at the discretion of the attending physician to determine whether AF had recurred or not. In patients for whom AF became chronic despite antiarrhythmic drug therapy, $\beta$-blockers, $\mathrm{Ca}$ antagonists, or digitalis were administered orally to control ventricular rate.

Prior to publication of JCS guidelines in November $2001,{ }^{15)}$ antithrombotic therapy was performed according to the method chosen by the attending physician. After this date, therapy was selected in accordance with the guidelines, with the appropriateness of therapy always decided by the attending physician. Anticoagulant therapy with warfarin was administered to patients having at least one risk factor for thromboembolism (history of ischemic stroke or transient ischemic attack, and presence of hypertension, diabetes mellitus, heart failure or coronary artery disease). For patients free of risk factors, antithrombotic therapy was not applied if the patient was younger than 60 years, antiplatelet therapy with aspirin or anticoagulant therapy with warfarin was applied for age 60-75, and anticoagulant therapy with warfarin was applied for age over 75 years. Aspirin was administered at a dose of 81-100 mg/day, while the international normalized ratio was adjusted (target INR: 1.6-3.0) in accordance with the guidelines for warfarin therapy. After publication of the JCS guidelines in December 2008, ${ }^{\text {, }}$ anticoagulant therapy was only performed in the outpatient clinic to obtain the target INR (1.6-3.0).

Noninvasive examinations, including chest X-rays, exercise tests, and transthoracic echocardiography were performed in all patients, while pulmonary function tests, computed tomographic examination of the brain and chest, and cardiac catheterization were performed at the discretion of the attending physician. Patients with severe bradyarrhythmia (sick sinus syndrome, atrioventricular block, or intraventricular conduction disorder), those with hepatic or renal dysfunction associated with laboratory abnormalities, women with child-bearing potential, and patients receiving concomitant $\beta$-blockers or Ttype calcium antagonists during antiarrhythmic drug therapy were excluded from the study. This study was conducted between June 1993 and August 2010, with a mean observation period of $49 \pm 32$ months.

Definitions: Based on the symptoms and ambulatory 24-hour monitoring, paroxysmal AF was defined as transient AF terminating spontaneously within 1 week of onset. ${ }^{16)}$ The history of AF was the period from the initial episode of AF to the time of initiation of antiarrhythmic therapy. Permanent AF was defined as AF that was refractory to pharmacological and electrical cardioversion and did not convert to sinus rhythm for a period greater than 6 months. Asymptomatic AF was defined as an AF episode in which patients had none of the symptoms associated with arrhythmia such as palpitations, dizziness, chest discomfort or syncope, or heart failure symptoms such as dyspnea, edema, orthopnea, or paroxysmal nocturnal dyspnea upon the initial hospital visit. ${ }^{17)}$ Cerebral thromboembolism was diagnosed in all cases based on typical neurological symptoms and the development of a new low-density lesion greater than $3 \mathrm{~mm}$ on brain computed tomographic examination or magnetic resonance imaging, which was performed in all patients. Hypertension was defined according to the Japanese Society of Hypertension Guidelines for the Management of Hypertension (JSH 2009). ${ }^{18)}$ Diabetes mellitus was diagnosed if fasting venous blood glucose was $\geq 126 \mathrm{mg} / \mathrm{dL}$ or hemoglobin $\mathrm{A}_{1} \mathrm{C}$ was $\geq 6.5 \%$. Dyslipidemia was defined as a fasting plasma concentration of cholesterol greater than $220 \mathrm{mg} / \mathrm{dL}$ and a fasting plasma acylglycerol level greater than $150 \mathrm{mg} / \mathrm{dL} .{ }^{19)}$ Onset of paroxysmal AF was classified as diurnal type (07:00 to 17:00), nocturnal type (17:00 to 07:00 next morning), or mixed type (AF occurring irrespective of circadian variation) based on standard 12-lead ECG and ambulatory 24-hour monitoring findings. In patients with $\mathrm{AF}$ at the time of a hospital visit, classification was based on the time when symptoms commenced. ${ }^{20)}$ Recurrence of AF was not determined from subjective symptoms, but was defined as the time when ECG first revealed $\mathrm{AF}$ during antiarrhythmic drug therapy. In the pulmonary function test, we regarded FEV1.0 $\leq 70 \%$ as a diagnostic criterion for chronic obstructive pulmonary disease. Risk factors for thromboembolism regarding $\mathrm{CHADS}_{2}$ scores were defined as 
a history of cerebral infarction or transient ischemic attack, hypertension, diabetes mellitus, coronary artery disease, or recent heart failure. $^{21)}$

Statistical analysis: Demographic data on patient characteristics were expressed as the mean \pm standard deviation. For statistical comparison between the two groups, clinical characteristics in individual patients were compared between the groups by the Mann-Whitney $U$-test for continuous variables and the chi-square test for categorical variables. Survival curves were estimated by the Kaplan-Meier method and compared by the log-rank test (Cox-Mantel). Multivariate logistic regression analysis with the enter method was used to adjust the influence of statin therapy for other confounding variables. The model was tested with the Hosmer-Lemeshow goodness-of-fit test. Statistical analysis was performed using the SPSS 13.0 statistical package (SPSS; Chicago, IL). $P$ values $<0.05$ were considered as significant differences.

\section{Results}

Comparison of clinical profiles: The percentage of patients treated with antiplatelet drugs was significantly higher in the pravastatin group $(39 \%)$ than in the atorvastatin group $(9 \%)(P$ $<0.01)$. On the other hand, the percentage of patients treated with anticoagulants was significantly higher in the atorvastatin group $(63 \%)$ than in the pravastatin group $(24 \%)(P<0.01)$. In terms of other background variables including antiarrhythmic drugs and underlying heart disease, there were no significant differences between the two groups (Tables I, IIA and IIB).

Table I. Patient Characteristics - Clinical Profile

\begin{tabular}{|c|c|c|c|}
\hline & Pravastatin & Atorvastatin & $P$ \\
\hline Numbers & 41 & 43 & \\
\hline Age (years) & $67 \pm 9$ & $65 \pm 10$ & NS \\
\hline Male:female & $19: 22$ & $26: 17$ & NS \\
\hline Hypertension (\%) & $16(39 \%)$ & $24(56 \%)$ & NS \\
\hline Diabetes mellitus (\%) & $6(15 \%)$ & $13(30 \%)$ & NS \\
\hline Smoking (\%) & $8(20 \%)$ & $2(5 \%)$ & NS \\
\hline Alcohol (\%) & $9(22 \%)$ & $12(28 \%)$ & NS \\
\hline Hyperuricemia (\%) & $4(10 \%)$ & $4(9 \%)$ & NS \\
\hline Organic heart disease $(\%)$ & $13(32 \%)$ & $7(16 \%)$ & NS \\
\hline Organic pulmonary disease $(\%)$ & $3(7 \%)$ & $2(5 \%)$ & NS \\
\hline Asymptomaic AF (\%) & $4(10 \%)$ & $2(5 \%)$ & NS \\
\hline AF history (months) & $17.9 \pm 31.3$ & $12.9 \pm 22.5$ & NS \\
\hline $\mathrm{CRP}(\mathrm{mg} / \mathrm{dL})$ & $0.42 \pm 0.21$ & $0.46 \pm 0.28$ & NS \\
\hline LVDd (mm) & $46.7 \pm 4.9$ & $44.6 \pm 5.4$ & NS \\
\hline $\mathrm{LAD}(\mathrm{mm})$ & $36.6 \pm 6.8$ & $41.3 \pm 6.6$ & NS \\
\hline $\operatorname{LVEF}(\%)$ & $70.0 \pm 10.1$ & $68.6 \pm 9.2$ & NS \\
\hline RAAS inhibitors (\%) & $8(20 \%)$ & $15(35 \%)$ & NS \\
\hline $\mathrm{CHADS}_{2}$ score & $1.1 \pm 1.1$ & $1.4 \pm 1.1$ & NS \\
\hline \multicolumn{4}{|l|}{ Antithrombotic drugs } \\
\hline$\bullet$ •nil (\%) & $15(37 \%)$ & $12(28 \%)$ & NS \\
\hline -antiplatelet drugs (\%) & $16(39 \%)$ & $4(9 \%)$ & $<0.01$ \\
\hline -oral anticoagulants (\%) & $10(24 \%)$ & $27(63 \%)$ & $<0.01$ \\
\hline ANP during SR (pg/mL) & $35.2 \pm 35.1$ & $33.4 \pm 23.2$ & NS \\
\hline \multicolumn{4}{|l|}{ Onset of paroxysmal AF } \\
\hline •diurnal: nocturnal: mixed & $8: 16: 17$ & $6: 13: 24$ & NS \\
\hline
\end{tabular}

AF indicates atrial fibrillation; CRP, C-reactive protein; LVDd, left ventricular diastolic dimension; LAD, left atrial dimension; LVEF, left ventricular ejection fraction; RAAS, renin-angiotensin-aldosterone system; and ANP, atrial natriuretic peptide.
The plasma concentration of total cholesterol in the atorvastatin group was $274.6 \pm 37.9 \mathrm{mg} / \mathrm{dL}$ at baseline and significantly reduced to $192.5 \pm 35.7 \mathrm{mg} / \mathrm{dL}$ after therapy $(P<0.01)$, and that of LDL cholesterol in the atorvastatin group was $188.2 \pm 39.7 \mathrm{mg} / \mathrm{dL}$ at baseline and significantly reduced to $112.4 \pm 34.8 \mathrm{mg} / \mathrm{dL}$ after therapy $(P<0.01)$. On the other hand, the plasma concentration of total cholesterol in the pravastatin group was $277.3 \pm 41.6 \mathrm{mg} / \mathrm{dL}$ at baseline and significantly reduced to $235.9 \pm 42.6 \mathrm{mg} / \mathrm{dL}$ after therapy $(P<0.01)$, and that of LDL cholesterol in the pravastatin group was 192.7 $\pm 39.1 \mathrm{mg} / \mathrm{dL}$ at baseline and significantly reduced to $147.8 \pm$ $40.3 \mathrm{mg} / \mathrm{dL}$ after therapy $(P<0.01)$.

Long-term prophylactic efficacy of antiarrhythmic drug therapy: Survival rates free from AF recurrence at 1, 6, 12, and 24 months were $93 \%, 74 \%, 60 \%$, and $53 \%$, respectively, in the atorvastatin group, and $88 \%, 49 \%, 37 \%$, and $29 \%$, respectively, in the pravastatin group. The rate was significantly higher in the atorvastatin group at 24 months (Figure $1, P=0.0288$ ). Survival rates free from conversion to permanent AF at 12, 36, 60 , and 90 months were $100 \%, 100 \%, 98 \%$, and $95 \%$, respectively, in the atorvastatin group, and $100 \%, 95 \%, 88 \%$, and $83 \%$, respectively, in the pravastatin group, indicating a slight difference between the atorvastatin and pravastatin groups at 90 months (Figure 2, $P=0.0628$ ).

Odds ratio for AF recurrence on atorvastatin versus pravastatin: Using a logistic regression model, atorvastatin was associated with a significantly reduced risk of developing $\mathrm{AF}$ recurrence in comparison to pravastatin (unadjusted $\mathrm{OR}=0.27$, $95 \%$ confidence interval $0.11-0.68, P=0.005)$. This association remained significant after adjustment for potentially confounding variables including age, sex, hypertension, diabetes mellitus, underlying heart disease, treatment with RAAS inhibitors, AF history, and echocardiographic parameters in a

Table IIA. Patient Characteristics - Underlying Heart Disease

\begin{tabular}{lccc}
\hline & Pravastatin & Atorvastatin & $P$ \\
\hline Old myocardial infarction & $3(23 \%)$ & $3(43 \%)$ & NS \\
Angina pectoris & $3(23 \%)$ & $0(0 \%)$ & NS \\
Hypertrophic cardiomyopathy & $0(0 \%)$ & $1(14 \%)$ & NS \\
Cardiac valvular disease & $3(23 \%)$ & $3(43 \%)$ & NS \\
Syndrome X & $2(16 \%)$ & $0(0 \%)$ & NS \\
Atrial septal defect & $1(8 \%)$ & $0(0 \%)$ & NS \\
Sick sinus syndrome & $1(8 \%)$ & $0(0 \%)$ & NS \\
\hline \multicolumn{1}{c}{ Total } & 13 & 7 &
\end{tabular}

Table IIB. Patient Characteristics - Antiarrhythmic Therapy

\begin{tabular}{|c|c|c|c|}
\hline & Pravastatin & Atorvastatin & $P$ \\
\hline Disopyramide & $9(22 \%)$ & $4(9 \%)$ & NS \\
\hline Aprindine & $6(15 \%)$ & $2(5 \%)$ & NS \\
\hline Cibenzoline & $9(22 \%)$ & $9(21 \%)$ & NS \\
\hline Pilsicainide & $9(22 \%)$ & $9(21 \%)$ & NS \\
\hline Flecainide & $2(5 \%)$ & $3(7 \%)$ & NS \\
\hline Propafenone & $1(2 \%)$ & $4(9 \%)$ & NS \\
\hline Pirmenol & $0(0 \%)$ & $2(5 \%)$ & NS \\
\hline Bepridil & $4(10 \%)$ & $8(19 \%)$ & NS \\
\hline Amiodarone & $1(2 \%)$ & $2(5 \%)$ & NS \\
\hline
\end{tabular}




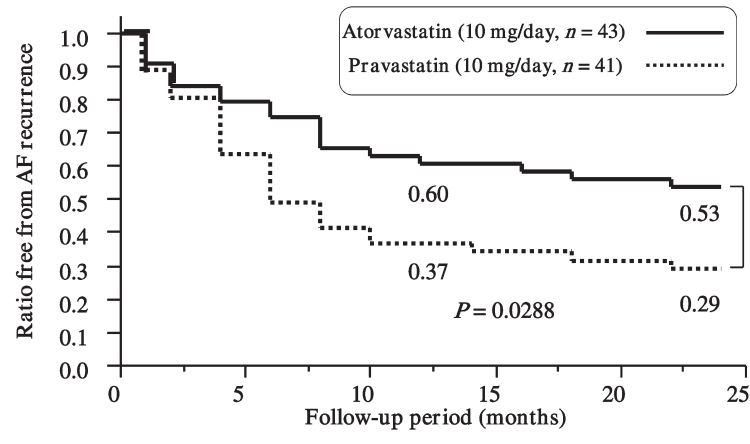

Figure 1. Survival curve free from $A F$ recurrence after upstream therapy with statins in patients on antiarrhythmic drugs. AF indicates atrial fibrillation. $\mathrm{AF}$ recurrence was not determined from subjective symptoms, but was defined according to the time when ECG first revealed AF during the follow-up period.

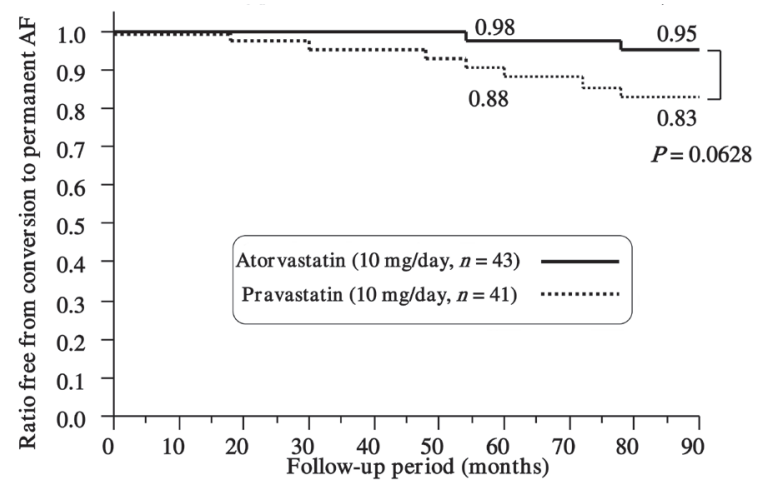

Figure 2. Survival curve free from conversion to permanent AF after upstream therapy with statins in patients on antiarrhythmic drugs. AF indicates atrial fibrillation. Permanent AF was defined as AF that was refractory to pharmacological or electrical cardioversion and did not convert to sinus rhythm for a period greater than 6 months.

multivariate model $(\mathrm{OR}=0.26,95 \% \mathrm{CI} 0.08-0.86, P=0.027)$. Using a logistic regression model, atorvastatin was not associated with a significantly reduced risk of converting to permanent $\mathrm{AF}$ in comparison to pravastatin (unadjusted $\mathrm{OR}=0.29$, $95 \%$ CI $0.05-1.50, P=0.138$ ), while this association changed to a significant difference after adjustment for the same potentially confounding variables in a multivariate model $(\mathrm{OR}=$ $0.08,95 \%$ CI $0.06-0.96, P=0.046$ ).

Adverse effects requiring discontinuation of statins: An adverse effect requiring statin discontinuation was observed in 1 case $(2 \%$, myalgia) in the atorvastatin group, and in 1 case $(2 \%$, elevation in $\mathrm{CPK}$ level $\geq 500 \mathrm{IU} / \mathrm{L})$ in the pravastatin group (Figure 3, $P=\mathrm{NS}$ ).

\section{Discussion}

Main findings: The present study has demonstrated that the efficacy of atorvastatin was significantly superior to that of pravastatin as an upstream therapy in combination with antiarrhythmic

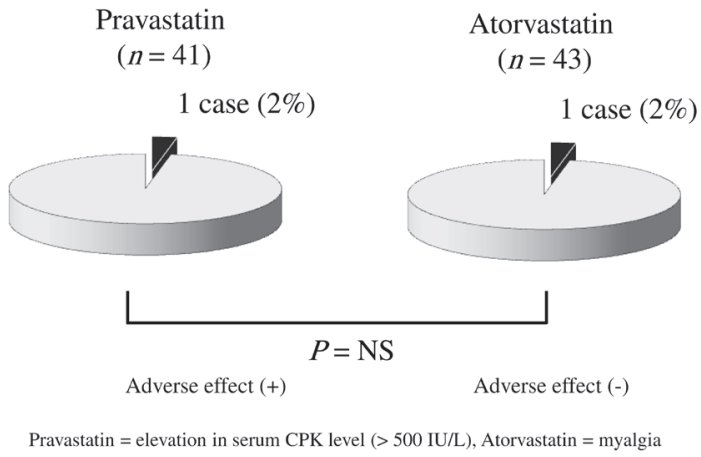

Figure 3. Adverse effects requiring discontinuation of statins.

drug therapy for preventing recurrence of $\mathrm{AF}$ and maintaining sinus rhythm. In a logistic regression model, atorvastatin was associated with a significantly reduced risk of AF recurrence and conversion to permanent AF after adjustment for potentially confounding variables in comparison to pravastatin.

Relationship between AF and inflammation: Atrial biopsy in patients with lone AF which is refractory to antiarrhythmic agents in maintaining sinus rhythm reveals pathological changes such as infiltration of inflammatory cells, necrosis, and fibrosis. ${ }^{22)}$ Plasma concentrations of high-sensitivity C-reactive protein (hs-CRP), which reflect the degree of inflammation, are significantly elevated in these patients compared to those with normal sinus rhythm. ${ }^{23,24)}$ The inflammation of atrial muscle in patients with paroxysmal AF has been suggested to be lesser in degree compared to that in patients with permanent AF according to plasma concentrations of hs-CRP. ${ }^{23)}$ In addition, many studies of atrial flutter or fibrillation in experimental animal models have used sterile pericarditis, ${ }^{25,26)}$ and AF was observed after cardiac surgery in $10 \%$ to $40 \%$ of patients. ${ }^{27,28)}$ Thus, chronic inflammation of atrial myocardium is implicated in the pathogenesis of AF. Further studies have shown that electrophysiological properties of AF such as a shortened refractory period and reduction in conduction velocity whereby AF can easily be induced and prolonged are exacerbated by inflammation of the atrium. ${ }^{26)}$ Namely, inflammation strongly contributes to the formation of the arrhythmogenic substrate required for the reentry circuit in $\mathrm{AF}$.

Pharmacological mechanism of statins on AF: There is a substantial amount of data indicating that in addition to their lipid lowering action, statins also modulate inflammation, ${ }^{29)}$ oxidative stress, ${ }^{30)}$ proliferation, ${ }^{31)}$ and nitric oxide-dependent endothelial function. ${ }^{32)}$ However, there is little information to show that different statin treatment regimens exert different pleiotropic actions. Several studies have demonstrated that the efficacy of statins for cardio-protection of endothelial function, ${ }^{11)}$ and their anti-oxidative, ${ }^{12)}$ anti-inflammatory ${ }^{13)}$ and antiproliferative ${ }^{14)}$ actions were more pronounced with atorvastatin than with pravastatin. Atorvastatin is also considered to have a superior affinity for cardiac cellular membrane than pravastatin, since atorvastatin is a lipophilic statin whereas pravastatin is a hydrophilic statin.

Clinical efficacy of statins in AF: Most of the randomized trials $^{8,33,34)}$ and meta-analyses ${ }^{9,35,36)}$ in large-scale clinical studies have shown similar results with respect to the beneficial effica- 
Table IIIA. Large-Sscale Randomized Trials and Meta-Analyses of Statins Therapy

\begin{tabular}{|c|c|c|c|}
\hline Authors & $\begin{array}{l}\text { Study design } \\
\text { (Follow-up periods) }\end{array}$ & Study subjects & Key findings on AF recurrence \\
\hline Fauchier, et al & $\begin{array}{l}\text { Meta-analysis of } 6 \text { randomized } \\
\text { trials }\end{array}$ & $\begin{array}{l}3557 \text { AF patients undergoing All statins versus no statins } \\
\text { electrical cardioversion and car- } \\
\text { diac surgery }\end{array}$ & $\begin{array}{l}\text { Decreased relative risk by } 61 \% \\
(P=0.02)\end{array}$ \\
\hline Liakopoulos, et al & $\begin{array}{l}\text { Meta-analysis of } 3 \text { randomized } \\
\text { and } 16 \text { observational studies }\end{array}$ & $\begin{array}{l}31725 \text { AF patients undergoing All statins versus no statins } \\
\text { cardiac surgery }\end{array}$ & $\begin{array}{l}\text { Decreased absolute relative risk by } \\
1.5 \%(P<0.0001)\end{array}$ \\
\hline Patel, et al & $\begin{array}{l}\text { Meta-analysis of } 14 \text { randomized } \\
\text { and observational studies }\end{array}$ & $\begin{array}{l}7402 \text { AF patients caused by any All statins versus no statins } \\
\text { mechanisms }\end{array}$ & $\begin{array}{l}\text { Decreased relative risk by } 45 \% \\
(P=0.001)\end{array}$ \\
\hline Liu, et al & $\begin{array}{l}\text { Meta-analysis of } 6 \text { randomized } \\
\text { and } 10 \text { observational studies }\end{array}$ & $\begin{array}{l}7041 \text { AF patients caused by any All statins versus no statins } \\
\text { mechanisms }\end{array}$ & $\begin{array}{l}\text { Decreased relative risk by } 24 \% \\
(P=0.09)\end{array}$ \\
\hline Maggioni, et al & $\begin{array}{l}\text { GISSI-AF: a randomized dou- } \\
\text { ble-blind, placebo-controlled } \\
\text { study } \\
(3.2 \pm 1.5 \text { years })\end{array}$ & $\begin{array}{l}3690 \text { AF patients with heart Rosuvastatin }(10 \mathrm{mg} / \mathrm{day}) \\
\text { failure } \\
\text { versus placebo }\end{array}$ & $\begin{array}{l}\text { Decreased relative risk adjusted for } \\
\text { clinical variables, laboratory examina- } \\
\text { tions and background therapy by } 18 \% \\
(P=0.038)\end{array}$ \\
\hline Hanna, et al & $\begin{array}{l}\text { ADVANCENT(SM): a mulicen- } \\
\text { ter registry }\end{array}$ & $\begin{array}{l}25268 \mathrm{AF} \text { patients with impaired All statins versus no statins } \\
\text { cardiac function } \\
(\mathrm{LVEF}<40 \%)\end{array}$ & $\begin{array}{l}\text { Decreased relative risk by } 31 \% \\
(P=0.001)\end{array}$ \\
\hline \multirow[t]{2}{*}{ McLean, et al } & $\begin{array}{l}\text { PROVE IT-TIMI } 22 \text { trial } \\
\text { (a randomized trial: } 24 \text { months) }\end{array}$ & $\begin{array}{l}4162 \text { AF patients with acute } \\
\text { coronary syndrome } \quad \text { Standard-dose versus high- }\end{array}$ & $\begin{array}{l}\text { Decreased relative risk by } 16 \% \\
(P=0.41)\end{array}$ \\
\hline & $\begin{array}{l}\text { Phase } \mathrm{Z} \text { of the } \mathrm{A} \text { to } \mathrm{Z} \text { trial } \\
\text { (a randomized study: } 721 \text { days) }\end{array}$ & $\begin{array}{l}4497 \text { AF patients with acute dose statins } \\
\text { coronary syndrome }\end{array}$ & $\begin{array}{l}\text { Increased relative risk by } 60 \% \\
(P=0.10)\end{array}$ \\
\hline Adabag, et al & $\begin{array}{l}\text { Cohort study } \\
\text { ( } 4.8 \text { years) }\end{array}$ & $\begin{array}{l}13783 \text { AF patients with coro- All statins versus no statins } \\
\text { nary artery disease and heart } \\
\text { failure }\end{array}$ & $\begin{array}{l}\text { No difference in AF incidence with } \\
\text { statin } \\
\text { Decreased relative risk in patients } \\
\text { with heart failure }(P=0.04) \text { by } 43 \%\end{array}$ \\
\hline
\end{tabular}

Table IIIB. Recent Studies on Atorvastatin and Pravastatin Therapy

\begin{tabular}{|c|c|c|c|c|}
\hline Authors & $\begin{array}{c}\text { Study design } \\
\text { (Follow-up periods) }\end{array}$ & Study subjects & Drug tested & Key findings on AF recurrence \\
\hline Demellis, et al & Prospective study (4-6 months) & 80 paroxysmal AF patients & $\begin{array}{l}\text { Atorvastatin }(20-40 \mathrm{mg} / \text { day }) \\
\text { versus placebo }\end{array}$ & $\begin{array}{l}\text { Decreased relative risk by } 55 \% \\
(P<0.001)\end{array}$ \\
\hline Ozaydin, et al & Prospective study (3 months) & $\begin{array}{l}99 \mathrm{AF} \text { patients lasting }>48 \text { hours } \\
\text { after electrical cardioversion }\end{array}$ & $\begin{array}{l}\text { Atorvastatin ( } 10 \mathrm{mg} / \text { day) } \\
\text { versus placebo }\end{array}$ & $\begin{array}{l}\text { Decreased relative risk by } 77 \% \\
(P=0.024)\end{array}$ \\
\hline Tsai, et al & $\begin{array}{l}\text { Open-label prospective ran- } \\
\text { domized study ( } 1 \text { year) }\end{array}$ & $\begin{array}{l}106 \mathrm{AF} \text { patients with pacemak- } \\
\text { er }\end{array}$ & $\begin{array}{l}\text { Atorvastatin ( } 20 \mathrm{mg} / \text { day) } \\
\text { versus no statins }\end{array}$ & $\begin{array}{l}\text { Decreased relative risk by } 70 \% \\
(P=0.041)\end{array}$ \\
\hline Patti, et al & $\begin{array}{l}\text { Prospective randomized study } \\
\text { (30 days) }\end{array}$ & $\begin{array}{l}200 \text { AF patients undergoing } \\
\text { cardiopulmonary bypass }\end{array}$ & $\begin{array}{l}\text { Atorvastatin ( } 40 \mathrm{mg} / \text { day) } \\
\text { versus placebo }\end{array}$ & $\begin{array}{l}\text { Decreased relative risk by } 40 \% \\
(P=0.003)\end{array}$ \\
\hline Siu, et al & $\begin{array}{l}\text { Retrospective observational study } \\
\text { ( } 44 \text { months) }\end{array}$ & $\begin{array}{l}62 \text { lone AF patients lasting }>3 \\
\text { months after electrical cardio- } \\
\text { version }\end{array}$ & $\begin{array}{l}\text { Atorvastatin (10 mg/day) } \\
\text { or simvastatin ( } 20 \mathrm{mg} / \text { day })\end{array}$ & $\begin{array}{l}\text { Decreased relative risk by } 69 \% \\
(P=0.032)\end{array}$ \\
\hline Naji, et al & $\begin{array}{l}\text { Retrospective observational study } \\
\text { (>2 years) }\end{array}$ & $\begin{array}{l}65 \text { persisient } \mathrm{AF} \text { patients after } \\
\text { electorical cardioversion }\end{array}$ & $\begin{array}{l}\text { Atrovastatin ( } 10 \text { or } 20 \mathrm{mg} / \text { day }) \\
\text { vs simvastatin ( } 20 \text { or } 40 \mathrm{mg} \text { / } \\
\text { day) }\end{array}$ & $\begin{array}{l}\text { Decreased relative risk in atorvas- } \\
\text { tatin group }(P=0.02) \text { by } 69 \%\end{array}$ \\
\hline Tveit, et al & Prospective study (6 weeks) & $\begin{array}{l}114 \mathrm{AF} \text { patients lasting }>48 \text { hours } \\
\text { after electrical cardioversion }\end{array}$ & $\begin{array}{l}\text { Pravastatin ( } 40 \mathrm{mg} / \mathrm{day} \text { ) } \\
\text { versus placebo }\end{array}$ & $\begin{array}{l}\text { Increased relative risk by } 6 \% \\
(P>0.999)\end{array}$ \\
\hline Komatsu, et al & $\begin{array}{l}\text { Retrospective observational study } \\
\text { ( } 48 \text { months) }\end{array}$ & 318 paroxysmal AF patients & $\begin{array}{l}\text { Pravastatin (10 mg/day) } \\
\text { versus no statins }\end{array}$ & $\begin{array}{l}\text { Pravastatin significantly reduced } \\
\text { AF recurrence versus no statins } \\
(10 \% \text { versus } 25 \%, P=0.029)\end{array}$ \\
\hline
\end{tabular}


cy of statins in AF, but no benefit was found in two studies ${ }^{37,38)}$ (Table IIIA). Subgroup analysis revealed that differences in AF detection methodology and patient characteristics may have been the cause of the heterogeneity. The benefit of statin therapy seemed more marked in the postoperative ${ }^{37)}$ and secondary prevention of AF. ${ }^{9)}$ Previous clinical studies evaluating the efficacy of atorvastatin and pravastatin on recurrence of AF have been conducted in patients with paroxysmal form, ${ }^{39)}$ persistent form lasting 48 hours or longer after electrical cardioversion, ${ }^{40-42)}$ and postoperative $\mathrm{AF}^{43)}$ over short follow-up periods ${ }^{39,40,42,43)}$ (Table IIIB). In contrast, few studies have examined the efficacy of statins in patients with paroxysmal ${ }^{44)}$ and persistent AF on a long-term basis (> 2 years). ${ }^{41,45)}$ Pravastatin, a hydrophilic statin, was considered to be effective for preventing recurrence of $\mathrm{AF}$ after electrical cardioversion in a retrospective study, whereas its efficacy was neglected in a randomized open-label multicenter study. ${ }^{42)}$ However, atorvastatin, a lipophilic statin, was demonstrated to be effective for preventing recurrence of paroxysmal and persistent $\mathrm{AF}$ in a prospective randomized study. ${ }^{40,46)}$ A prospective, randomized, double-blind, placebo-controlled study initiated treatment with atorvastatin 1 week before elective cardiac surgery and showed a significant reduction in the incidence of postoperative $\mathrm{AF}^{43}$ ) In addition, Naji, et al reported that atorvastatin was superior to simvastatin for preventing recurrence of persistent AF after electrical cardioversion in their retrospective study. ${ }^{45)}$ Our results were similar to those of Naji, et al showing atorvastatin to be more effective in preventing recurrence of paroxysmal AF than pravastatin. These results suggest that different types of statin treatments exert different levels of efficacy in preventing recurrence of paroxysmal AF.

Limitations: Our study has the following limitations: First, as this was a retrospective observational study, there were differences in the stage at which atorvastatin or pravastatin was given to prevent the recurrence of AF during follow-up periods, and some bias may exist in the demographic data relating to each group. There were significant differences in the percentage use of antithrombotic therapy between the two groups in this study, but to the best of our knowledge no previous studies have reported on the efficacy of antithrombotic drugs for preventing recurrence of AF. Secondly, recurrence of AF was diagnosed at the time of detection of AF on ECG. A study using ambulatory 24-hour monitoring reported that more than half of AF episodes were not recognized by patients with paroxysmal AF who had obvious symptoms. ${ }^{47)}$ On the other hand, a study using an ambulatory ECG monitor (Cardiophone) reported that $30 \%$ to $70 \%$ of patients with symptomatic AF developed sinus tachycardia or premature atrial contractions when they complained of palpitations. ${ }^{48)}$ In other words, present detection methods based on ECG findings have methodological limitations in accurately detecting AF recurrence. ${ }^{49)}$ Thirdly, since statins have several pleiotrophic actions, ${ }^{11-14)}$ it was not known which pharmacological action of the drug was effective in each case. Fourthly, since the present study targeted patients with paroxysmal AF only, it was not known how effective statins were in preventing persistent AF. Fifthly, it may be necessary to compare the efficacy of atorvastatin or pravastatin as an upstream therapy at the same lipid-lowering levels for decreasing the plasma concentration of total cholesterol. Lastly, the sample size of the present study was relatively small.

It may therefore be necessary to conduct a prospective controlled multicenter study in Japan in order to reevaluate the efficacy and safety of statins in a larger patient population with paroxysmal and persistent AF.

Conclusion: Our findings suggest that atorvastatin, a lipophilic statin, is more effective in preventing recurrence of paroxysmal $\mathrm{AF}$ and conversion to permanent $\mathrm{AF}$ than pravastatin, a hydrophilic statin.

\section{ACKnowledgments}

We thank all study participants, as well as the physicians and medical staff of Iwate Medical University. We are also deeply grateful for the direction provided by Professor Ken Okumura of Hirosaki University School of Medicine (Aomori, Japan).

\section{REFERENCES}

1. Benjamin EJ, Wolf PA, D'Agostino RB, Silbershatz H, Kannel WB, Levy D. Impact of atrial fibrillation on the risk of death: the Framingham Heart Study. Circulation 1998; 98: 946-52.

2. Wolf PA, Abbott RD, Kannel WB. Atrial fibrillation: a major contributor to stroke in the elderly. The Framingham study. Arch Intern Med 1987; 147: 1561-4.

3. Dries DL, Exner DV, Gersh BJ, Domanski MJ, Waclawiw MA, Stevenson LW. Atrial fibrillation is associated with an increased risk for mortality and heart failure progression in patients with asymptomatic and symptomatic left ventricular dysfunction: a retrospective analysis of the SOLVD trials. Studies of Left Ventricular Dysfunction. J Am Coll Cardiol 1998; 32: 695-703.

4. Miyasaka Y, Barnes ME, Gersh BJ, et al. Secular trends in incidence of atrial fibrillation in Olmsted County, Minnesota, 1980 to 2000 , and implications on the projections for future prevalence. Circulation 2006; 114: 119-25.

5. Ohsawa M, Okayama A, Sakata K, et al. Rapid increase in estimated number of persons with atrial fibrillation in Japan: an analysis from national surveys on cardiovascular diseases in 1980, 1990 and 2000. J Epidemiol 2005; 15: 194-6.

6. Ogawa S, Aizawa Y, Okumura K, et al. The Japanese guidelines for pharmacotherapy of atrial fibrillation (JCS 2008). Circ J 2008; 72 (Supp IV): 1581-638. (Japanese)

7. Aizawa Y, Kohsaka S, Suzuki S, et al. Comparison of antiarrhythmics used in patients with paroxysmal atrial fibrillation: subanalysis of J-RHYTHM Study. Circ J 2010; 74: 71-6.

8. Maggioni AP, Fabbri G, Lucci D, et al. Effects of rosuvastatin on atrial fibrillation occurrence: ancillary results of the GISSI-HF trial. Eur Heart J 2009; 30: 2327-36.

9. Fauchier L, Pierre B, de Labriolle A, Grimard C, Zannad N, Babuty D. Antiarrhythmic effect of statin therapy and atrial fibrillation. A meta-analysis of randomized controlled trials. J Am Coll Cardiol 2008; 51: 828-35.

10. Komatsu T, Tachibana H, Sato Y, et al. Long-term efficacy of upstream therapy using angiotensin-converting enzyme inhibitors and statins in combination with antiarrhythmic agents for the treatment of paroxysmal atrial fibrillation. Int Heart J 2009; 50: 46576.

11. Wagner AH, Köhler T, Rückschloss U, Just I, Hecker M. Improvement of nitric oxide-dependent vasodilatation by HMG-CoA reductase inhibitors through attenuation of endothelial superoxide anion formation. Arterioscler Thromb Vasc Biol 2000; 20: 61-9.

12. Mason RP. Molecular basis of differences among statins and a comparison with antioxidant vitamins. Am J Cardiol 2006; 98 : 34P-41P. (Review)

13. Hognestad A, Aukrust P, Wergeland R, et al. Effects of conventional and aggressive statin treatment on markers of endothelial function and inflammation. Clin Cardiol 2004; 27: 199-203. 
14. Turner NA, Midgley L, O’Regan DJ, Porter KE. Comparison of the efficacies of five different statins on inhibition of human saphenous vein smooth muscle cell proliferation and invasion. J Cardiovasc Pharmacol 2007; 50: 458-61.

15. Kodama I, Aizawa Y, Okumura K, et al. The Japanese guidelines for pharmacotherapy of atrial fibrillation (JCS 2004). Circ J 2004; 68(SuppIV): 981-1053. (Japanese)

16. Sopher SM, Camm AJ. Atrial fibrillation: maintenance of sinus rhythm versus rate control. Am J Cardiol 1996; 77: 24A-37A. (Review)

17. Flaker GC, Belew K, Beckman K, et al. Asymptomatic atrial fibrillation: demographic features and prognostic information from the Atrial Fibrillation Follow-up Investigation of Rhythm Management (AFFIRM) study. Am Heart J 2005; 149: 657-63.

18. Ogihara T, Kikuchi K, Matsuoka H, et al. The Japanese Society of Hypertension Guidelines for the Management of Hypertension (JSH2009). Hypertens Res 2009; 32: 3-107.

19. Investigating Committee of Guideline for Diagnosis and Treatment of Hyperlipidemias: guidelines for diagnosis and treatment of hyperlipidemia in adults. J Jpn Atheroscler Soc 1997; 25: 1-34.

20. Komatsu T, Nakamura S, Suzuki O, Horiuchi D, Yomogida K, Okumura K. Long-term prognosis of patients with paroxysmal atrial fibrillation depends on their response to antiarrhythmic therapy. Circ J 2004; 68: 729-33.

21. Fuster V, Rydén LE, Cannom DS, et al. ACC/AHA/ESC guidelines for the management of patients with atrial fibrillation: executive summary: A report of the American College/American Heart Association Task Force on Practice Guidelines and the European Society of Cardiology Committee for Practice Guidelines and Policy Conferences Developed in Collaboration With the European Heart Rhythm Association and the Heart Rhythm Society. Circulation 2006; 114: e257-354.

22. Frustaci A, Chimenti C, Bellocci F, Morgante E, Russo MA, Maseri A. Histological substrate of atrial biopsies in patients with lone atrial fibrillation. Circulation 1997; 96: 1180-4.

23. Chung MK, Martin DO, Sprecher D, et al. C-reactive protein elevation in patients with atrial arrhythmias: inflammatory mechanisms and persistence of atrial fibrillation. Circulation 2001; 104: 2886-91.

24. Dernellis J, Panaretou M. C-reactive protein and paroxysmal atrial fibrillation: evidence of the implication of an inflammatory process in paroxysmal atrial fibrillation. Acta Cardiol 2001; 56: 37580.

25. Pagé PL, Plumb VJ, Okumura K, Waldo AL. A new animal model of atrial flutter. J Am Coll Cardiol 1986; 8: 872-9.

26. Kumagai K, Nakashima H, Saku K. The HMG-CoA reductase inhibitor atorvastatin prevents atrial fibrillation by inhibiting inflammation in a canine sterile pericarditis model. Cardiovasc Res 2004; 62: 105-11.

27. Aviles RJ, Martin DO, Apperson-Hansen C, et al. Inflammation as a risk factor for atrial fibrillation. Circulation 2003; 108: 3006-10.

28. Bruins $\mathrm{P}$, te Velthuis H, Yazdanbakhsh AP, et al. Activation of the complement system during and after cardiopulmonary bypass surgery: postsurgery activation involves $\mathrm{C}$-reactive protein and is associated with postoperative arrhythmia. Circulation 1997; 96: $3542-8$.

29. Weitz-Schmidt G. Statins as anti-inflammatory agents. Trends Pharmacol Sci 2002; 23: 482-6. (Review)

30. Shishehbor MH, Brennan ML, Aviles RJ, et al. Statins promote potent systemic antioxidant effects through specific inflammatory pathways. Circulation 2003; 108: 426-31.

31. Sacks FM. High-intensity statin treatment for coronary heart disease. JAMA 2004; 291: 1132-4.

32. Laufs U, La Fata V, Plutzky J, Liao JK. Upregulation of endothelial nitric oxide synthase by HMG CoA reductase inhibitors. Circu- lation 1998; 97: 1129-35.

33. Haana IR, Heeke B, Bush $\mathrm{H}$, et al. Lipid-lowering drug use is associated with reduced prevalence of atrial fibrillation in patients with left ventricular systolic dysfunction. Heart Rhythm 2006; 3: 881-6.

34. Adabag AS, Nelson DB, Bloomfield HE. Effects of statin therapy on preventing atrial fibrillation in coronary disease and heart failure. Am Heart J 2007; 154: 1140-5.

35. Liakopoulos OJ, Choi YH, Haldenwang PL, et al. Impact of preoperative statin therapy on adverse postoperative outcomes in patients undergoing cardiac surgery: a meta-analysis of over 30,000 patients. Eur Heart J 2008; 29: 1548-59. (Review)

36. Patel AA, White CM, Shah SA, Dale KM, Kluger J, Coleman CI. The relationship between statin use and atrial fibrillation. Curr Med Res Opin 2007; 23: 1177-85.

37. Liu T, Li L, Korantzopoulos P, Liu E, Li G. Statin use and development of atrial fibrillation: a systematic review and meta-analysis of randomized clinical trials and observational studies. Int J Cardiol 2008; 126: 160-70. (Review)

38. McLean DS, Ravid S, Blazing M, Gersh B, Shui A, Cannon CP. Effect of statin dose on incidence of atrial fibrillation: data from the Pravastatin or Atorvastatin Evaluation and Infection TherapyThrombolysis in Myocardial Infarction 22 (PROVE IT-TIMI 22) and Aggrastat to Zocor (A to Z) trials. Am Heart J 2008; 155: 298302.

39. Dernellis J, Panaretou M. Effect of C-reactive protein reduction on paroxysmal atrial fibrillation. Am Heart J 2005; 150: 1064.

40. Ozaydin M, Varol E, Aslan SM, et al. Effect of atorvastatin on the recurrence rates of atrial fibrillation after electrical cardioversion. Am J Cardiol 2006; 97: 1490-3.

41. Siu CW, Lau CP, Tse HF. Prevention of atrial fibrillation recurrence by statin therapy in patients with lone atrial fibrillation after successful cardioversion. Am J Cardiol 2003; 92: 1343-5.

42. Tveit A, Grundtvig M, Gundersen T, et al. Analysis of pravastatin to prevent recurrence of atrial fibrillation after electrical cardioversion. Am J Cardiol 2004; 93: 780-2.

43. Patti G, Chello M, Candura D, et al. Randomized trial of atorvastatin for reduction of postoperative atrial fibrillation in patients undergoing cardiac surgery: results of the ARMYDA-3 (Atorvastatin for Reduction of MYocardial Dysrhythmia After cardiac surgery) study. Circulation 2006; 114: 1455-61.

44. Komatsu T, Tachibana H, Sato Y, et al. Long-term efficacy of combination therapy with anti-arrhythmic agents and pravastatin in patients with paroxysmal atrial fibrillation. J Arrhythmia 2007; 23: $124-30$.

45. Naji F, Suran D, Kanic V, Vokac D, Sabovic M. Comparison of atorvastatin and simvastatin in prevention of atrial fibrillation after successful cardioversion. Int Heart J 2009; 50: 153-60.

46. Tsai CT, Lai LP, Hwang JJ, Wang YC, Chiang FT, Lin JL. Atorvastatin prevents atrial fibrillation in patients with bradyarrhythmias and implantation of an atrial-based or dual-chamber pacemaker: a prospective randomized trial. Am Heart J 2008; 156: 65-70.

47. Page RL, Wilkinson WE, Clair WK, McCarthy EA, Pritchett EL. Asymptomatic arrhythmias in patients with symptomatic paroxysmal atrial fibrillation and paroxysmal supraventricular tachycardia. Circulation 1994; 89: 224-7.

48. Fukuda Y, Akashi M, Noma S, et al. Asymptomatic recurrence of atrial fibrillation - Cardiophone-guided management. Circ J 2003; 67(Suppl I): 310.

49. Komatsu T, Tachibana H, Sato Y, Ozawa M, Kunugida F, Nakamura M. Efficacy of antiarrhythmic drug therapy in preventing recurrence of atrial fibrillation and long-term cardiovascular prognosis in patients with asymptomatic paroxysmal atrial fibrillation. Int Heart J 2010; 51: 98-104. 